\title{
Aberrant SOCS3 Promoter Methylation as a Noninvasive Diagnostic Biomarker for Locally Advanced Prostate Cancer
}

\section{Lokal IIlerlemiş Prostat Kanseri için Noninvaziv Diyagnostik Bir Biyobelirteç Olarak Sapmış SOCS3 Promotör Metilasyonu}

\author{
Berna DEMIRCAN TAN $\odot$, Turgay TURAN $\odot$, Burcu YUCEL $\odot$, Sedef ALTUNDAG KARA $\odot$, \\ Seda SALMAN YILMAZ $\odot$, Asif YILDIRIM $\odot$
}

Ethics Committee Approval: This study was approved by the Istanbul Medeniyet University Goztepe Training and Research Hospital Ethic Committee for Clinical Studies (25 April 2018, 2018/0124). Conflict of interest: The authors declare that they have no conflict of interest.

Funding: The Research Fund of Istanbul Medeniyet University supported this investigation (T-BAG2016-678).

Informed Consent: Informed consent was taken from all participants.

\section{ABSTRACT}

Objective: The aim of this study was to investigate the promoter methylation status of Rasassociated domain family $1 A$ (RASSF1A), O-6-methylguanine-DNA methyltransferase (MGMT), Phosphatase with tensin homology (PTEN) and Suppressor of cytokine signaling 3 (SOCS3) tumor suppressor genes and evaluate the clinical utility of these genes as noninvasive, bloodbased epigenetic biomarkers for the diagnosis of Prostate Cancer (PCa).

Method: A total of 41 consecutive patients and 10 healthy control groups were enrolled in the study. Pyrosequencing was performed to analyze the methylation levels of the promoter regions of the four tumor suppressor genes in patients compared to healthy controls.

Results: The promoter methylation levels of RASSF1A, MGMT, PTEN and SOCS3 did not differ between the patient and control groups. However, SOCS3 promoter methylation level was significantly higher for patients having locally advanced PCa compared to those having localized $P C a(p<0.05)$.

Conclusion: Our results indicated that SOCS3 could be a useful, noninvasive blood-based epigenetic biomarker for the diagnosis of locally advanced PCa.

Keywords: Prostate cancer, DNA methylation, epigenetics, SOCS3

öz

Amaç: Bu çalışmanın amacı tümör baskılayıcı genler Ras-associated domain family 1A (RASSF1A), O-6-methylguanine-DNA methyltransferase (MGMT), Phosphatase with tensin homology (PTEN) ve Suppressor of cytokine signaling 3 (SOCS3)'in promotör metilasyonlarını araştırmak ve bu genlerin Prostat Kanseri (PK) tanısı için noninvaziv, kan temelli epigenetik biyobelirteçler olarak klinik yararını değerlendirmekti.

Yöntem: 41 hasta ve 10 sağlıklı kontrol grubu çalışmaya kaydedildi. Dört tümör baskılayıcı genin promotör bölgelerinin metilasyon düzeylerini hastalarda sağlıklı kontrol grubuna kıyasla analiz etmek için pirodizileme gerçekleștirildi.

Bulgular: RASSF1A, MGMT, PTEN ve SOCS3 promotör metilasyon düzeyleri hasta ve konrol grubu arasında farklı değildi. Ancak SOCS3 promotör metilasyon düzeyi lokalize PK'lı hastalara kıyasla lokal olarak ilerlemiş PK'lı hastalarda önemli şekilde daha yüksekti $(p<0.05)$.

Sonuç: Sonuçlarımız SOCS3 ün lokal olarak ilerlemiş PK tanısında elverişli, noninvaziv kan temelli epigenetik biyobelirteç olabileceğini gösterdi.

Anahtar kelimeler: Prostat kanseri, DNA metilasyonu, epigenetikler, SOCS3
Received: 5 December 2019

Accepted: 12 April 2020

Online First: 30 June 2020

\section{Corresponding Author:}

B. Demircan Tan

ORCID: 0000-0001-9910-8713 Istanbul Medeniyet University,

Faculty of Medicine

Department of Medical Biology, Istanbul, Turkey

berna.demircan@medeniyet.edu.tr

\section{B. Yucel}

ORCID: 0000-0002-6599-4558

Istanbul Medeniyet University, Faculty of Medicine,

Department of Medical Biology, Istanbul, Turkey

T. Turan

ORCID: 0000-0002-4951-6396

A. Yildirim

ORCID: 0000-0002-3386-971X

Istanbul Medeniyet University,

Faculty of Medicine, Department of Urology, Istanbul, Turkey

S. Salman Yilmaz ORCID: 0000-0003-4215-0544 Istanbul University Cerrahpasa, Faculty of Medicine, Department of Medical Genetics, Istanbul, Turkey

S. Altundag Kara ORCID: 0000-0003-0283-8942 Istanbul Okan University, Faculty of Medicine, Department of Histology, Istanbul, Turkey 


\section{INTRODUCTION}

Prostate cancer (PCa) is the second most commonly diagnosed invasive cancer worldwide and the fifth most frequent cause of cancer deaths in men ${ }^{1}$. The clinical course of PCa is heterogeneous: Some cases are indolent and exhibit slow growth that is limited to the organ and do not progress if left untreated, whereas other cases can progress to lethal metastatic disease ${ }^{2,3}$. Clinical and pathological features such as Gleason score, tumor stage, and levels of prostate specific antigen (PSA) in blood can be used to determine aggressiveness of $\mathrm{PCa}^{4,5}$. For histological assessment of PCa, in 2014 the International Society of Urological Pathology (ISUP) recommended that a modified Gleason score be used as a new prognostic grading system. This modified grading system (ISUP 2014) was a better predictor of both biochemical and clinical recurrence compared to the Gleason scoring system ${ }^{6}$. Meanwhile, the PSA test is commonly performed to screen for PCa, but this test has both weak sensitivity and specificity that can result in overdiagnosis and overtreatment. Therefore, new molecular biomarkers are needed for the diagnosis and prognosis of PCa as well as for improved identification of potentially indolent $\mathrm{PCa}^{7}$.

Epigenetic and genetic changes are both common features of PCa. DNA methylation is an epigenetic change that regulates the differential expression of genes and involves covalent binding of a methyl group to the dinucleotide cytosine guanine at the $\mathrm{C}-5$ position of the cytosine ring. Methylation is mainly regulated by DNA methyltransferases (DNMTs). Hypermethylation of promoter CpG islands can silence tumor suppressor genes early during tumorigenesis, while global hypomethylation occurs later in the course of $\mathrm{PCa}^{7,8}$. A wide range of tumor suppressor genes have been reported to be epigenetically silenced by promoter DNA hypermethylation in PCa and these genes mainly regulate cell proliferation, DNA repair, apoptosis, tissue invasion and metastasis 9 . The gene encoding glutathione S-transferase-p1
(GSTP1) has been extensively studied for PCa, and its expression is inactivated in $>90 \%$ of cases with PCa due to aberrant DNA methylation of CPG islands in the promoter ${ }^{2,10,11}$. These methylation events seem to be involved during an early stage of prostatic carcinogenesis. Compared with PSA, serum levels of GSTP1 are more specific for PCa, since GSTP1 is not typically expressed in normal prostate tissue $^{11}$. Therefore, GSTP1 could serve as an epigenetic biomarker for detection of $\mathrm{PCa}^{7,12}$. Other genes that are frequently silenced by promoter DNA hypermethylation in PCa include APC, PTSG2, E-cadherin, RAR $\beta 2^{7}$. Since DNA methylation alterations are stable and easily measurable, differences in methylation patterns between normal and tumor cells could have potential application for the detection of tumor cells in biopsy specimens or body fluids $s^{7,13,14}$.

The aim of this study was to investigate the methylation status of Ras-associated domain family 1A (RASSF1A), O-6-methylguanine-DNA methyltransferase (MGMT), phosphatase with tensin homology (PTEN) and suppressor of cytokine signaling 3 (SOCS3) in blood from PCa patients and to evaluate the clinical utility of these genes as noninvasive, blood-based epigenetic biomarkers that could be used for PCa diagnosis.

\section{MATERIALS and METHODS}

\section{Study population and sample collection}

A total of 41 consecutive patients who were currently diagnosed with PCa but had not undergone radical prostatectomy or other therapies and 10 healthy control patients treated at the Urology Department of Istanbul Medeniyet University, Göztepe Training and Research Hospital were enrolled. The ethics committee at the Göztepe Training and Research Hospital approved the study protocol, and all enrolled patients provided signed informed consent for participation in the study. Peripheral blood samples $(5 \mathrm{ml})$ were obtained from each participant and stored at $-20^{\circ} \mathrm{C}$ until analysis. 


\section{DNA isolation}

DNA was isolated from all samples using a Qiagen QIAmp DNA mini kit (Qiagen CA, USA). Briefly, $20 \mu \mathrm{L}$ proteinase $\mathrm{K}$ and $200 \mu \mathrm{L}$ lysis buffer were added to $200 \mu \mathrm{L}$ blood samples. After incubation for 10 minutes at $56^{\circ} \mathrm{C}, 200 \mu \mathrm{L}$ ethanol was added. The mixture was transferred to QIAmp spin columns and centrifuged for $1 \mathrm{~min}$ at 8,000 rpm. The centrifugation was repeated several times after addition of related wash buffers and the purified DNA was eluted in $100 \mu \mathrm{L}$ Elution Buffer included in the kit. Concentrations of the isolated genomic DNA samples were measured using a NanodropTM spectrophotometer (Multiskan Go, Thermo Scientific, USA) and expressed as nanograms per microliter.

\section{Bisulfite modification of DNA samples}

Isolated genomic DNA samples were subjected to bisulfite deamination reactions using a Qiagen EpiTect Bisulfite kit (Qiagen, CA, USA) according to the manufacturer's instructions. Briefly, $500 \mathrm{ng}$ DNA was mixed in PCR tubes with $85 \mu \mathrm{L}$ bisulfite mix solution and $35 \mu \mathrm{L}$ DNA preservation buffer in a $200 \mu \mathrm{L}$ reaction. Samples were incubated in the thermal cycler device (Bio-Rad, USA) for 5 hours using the following reaction sequence: $95^{\circ} \mathrm{C}$ for $5 \mathrm{~min}$ followed by $25 \mathrm{~min}$ at $60^{\circ} \mathrm{C}, 5$ minutes at $95^{\circ} \mathrm{C}, 85 \mathrm{~min}$ at $60^{\circ} \mathrm{C}, 5 \mathrm{~min}$ at $95^{\circ} \mathrm{C}$ and $175 \mathrm{~min}$ at $60^{\circ} \mathrm{C}$. Samples were then transferred to Epitect spin columns before related buffers were added and the samples were centrifuged. Finally, the bisulfite-treated DNA samples were purified in 20 $\mu \mathrm{L}$ elution buffer.

\section{PyroMark PCR}

PCR reactions were conducted using a Qiagen PyroMark PCR kit (Qiagen, CA, USA). Briefly, 12.5 $\mu \mathrm{L}$ master mix, $2.5 \mu \mathrm{L}$ coral red, 5 pmol of each primer, $7 \mu \mathrm{L}$ water, and $2 \mu \mathrm{L}$ sample were mixed for each reaction and run under the following thermal cycling conditions: $95^{\circ} \mathrm{C}$ for $15 \mathrm{~min}$, followed by 45 cycles of $30 \mathrm{sec}$ at $94^{\circ} \mathrm{C}, 30 \mathrm{sec}$ at the optimized primer-specific annealing temperature, and $30 \mathrm{sec}$ at $72^{\circ} \mathrm{C}$, followed by a final extension step for $10 \mathrm{~min}$ at $72^{\circ} \mathrm{C}$. Amplification of the correct DNA products was confirmed by electrophoresis on a $2 \%$ low melting point agarose gel. Positive and negative controls were used for PyroMark PCR and pyrosequencing applications.

\section{PyroMark CpG Sequencing Analysis}

Quality-controlled PCR products were subjected to methylation analysis using PyroMark CpG assay sequencing (Qiagen, US). Briefly, CpG sequencing was completed in three steps: (1) immobilization of PCR products on Streptavidin-Sepharose beads according to the manufacturer's protocol; (2) PCRamplified DNA fragments were decomposed and transferred into a PyroMark Q24 plate using the Pyromark Workstation; (3) DNA was bound to sequence primers to initiate sequencing. For sequencing, Sepharose beads were mixed with $2 \mu \mathrm{L}$ streptavidin, $40 \mu \mathrm{L}$ binding buffer and $28 \mu \mathrm{L}$ ultradistilled water and combined with $10 \mu \mathrm{L}$ of PCR product from each sample in well-plates, which were incubated for $10 \mathrm{~min}$ at room temperature with shaking. Next, the mixture was transferred to a PyroMark Q24 plate wells with $2.5 \mu \mathrm{L} /$ sample primary sequence, and $22.5 \mu \mathrm{L} /$ sample Annealing Buffer/well. The PyroMark Workstation was prepared using $50 \mathrm{ml}$ 70\% ethanol, $40 \mathrm{ml}$ denaturation solution, $50 \mathrm{ml}$ wash buffer, and 50 and 70 $\mathrm{ml}$ ultra-distilled water. The plates were then transferred from the shaker to the Workstation. All PCR Sepharose-product complexes were subjected to vacuum filtration and sequentially washed with ethanol, denaturation solution and wash buffer for 10,10 and $15 \mathrm{sec}$, respectively. The vacuum was applied for a further $2 \mathrm{~min}$ and then turned off to allow transfer of the complexes to the sequence mixture in the PyroMark Q24 plate. The vacuum filters were washed extensively in the workstation to avoid contamination of subsequent samples.

The PyroMark Q24 plates were placed into the Pyromark Sequencer and sequencing reactions were carried out using appropriate cartridges containing relevant enzyme, substrate and adenine, cytosine, guanine, and thymine. Sequencing reactions 
were run on the PyroMark Q24 sequencer and methylation analyses were done using PyroMark Q24 Analysis software version 2.0.6. The presence of a $\mathrm{C}$ nucleotide instead of $\mathrm{T}$ (at position $\mathrm{Y}$ ) was interpreted as methylation, and methylation values are expressed as percentages.

\section{Statistical analysis}

Statistical analyses were performed using SPSS software version 22.0. In addition to descritive statistical values (mean, standard deviation), Student's $t$ test was used to evaluate patient characteristics. Methylation levels were compared by Pearson test. A P value of $<0.05$ was accepted as significant.

\section{RESULTS}

\section{Study Population}

In this prospective study, 21 localized and 20 locally advanced PCa were enrolled. The control group included 10 healthy age-matched men (mean age $69.9 \pm 5$ ) who had no evidence of PCa. The mean age of the PCa patients was $70.7 \pm 6.5$ years and the mean PSA level was $21.7 \pm 29 \mathrm{ng} /$ $\mathrm{ml}$ in the PCa, and $2.1 \pm 0.8 \mathrm{ng} / \mathrm{ml}$ in the control group. Clinical data was extracted from patient records. Patient characteristics are summarized in Tables 1 and 2.

Table 1. Baseline characteristics and correlation of promoter methylation levels for RASSF1A, MGMT, PTEN and SOCS3 in the study population.

\begin{tabular}{llll}
\hline & $\begin{array}{l}\text { Prostate cancer } \\
(\mathbf{n : 4 1})\end{array}$ & $\begin{array}{l}\text { Control } \\
(\mathbf{n}: 10)\end{array}$ & P-value \\
\hline $\begin{array}{l}\text { Age (years) } \\
\text { Mean } \pm \text { SD }\end{array}$ & $70.7 \pm 6.5$ & $69.9 \pm 5$ & $0.66^{\mathrm{a}}$ \\
$\begin{array}{l}\text { PSA Level (ng/ml) } \\
\text { Mean } \pm \text { SD }\end{array}$ & $21.7 \pm 29$ & $2.1 \pm 0.8$ & $0.002^{\mathrm{a}}$ \\
$\begin{array}{l}\text { Prostat Volume (ml) } \\
\text { Mean } \pm \text { SD }\end{array}$ & $41.6 \pm 19.1$ & $42.3 \pm 19.4$ & $0.92^{\mathrm{a}}$ \\
BMI (kg/m $)$ & & & \\
Mean \pm SD & $26.6 \pm 3.2$ & $25.9 \pm 1.8$ & $0.32^{\mathrm{a}}$ \\
RASSF1 A (\%) & 17.1 & 15.6 & $0.30^{\mathrm{b}}$ \\
MGMT (\%) & 7.1 & 7.3 & $0.82^{\mathrm{b}}$ \\
PTEN (\%) & 11.1 & 10.8 & $0.82^{\mathrm{b}}$ \\
SOCS3 (\%) & 2.25 & 2.23 & $0.95^{\mathrm{b}}$ \\
\hline
\end{tabular}

atudent t test

${ }^{b}$ Pearson correlation
Table 2. Patient characteristics and correlation of promoter methylation levels for RASSF1, MGMT, PTEN, and SOCS3 in localized and locally advanced PCa patient groups.

\begin{tabular}{llll}
\hline & $\begin{array}{l}\text { Localized } \\
\text { Prostate } \\
\text { Cancer } \\
\text { (n:21) }\end{array}$ & $\begin{array}{l}\text { Locally } \\
\text { Advanced } \\
\text { Prostate } \\
\text { Cancer } \\
\text { (n:20) }\end{array}$ & P-value \\
& & $71.4 \pm 6.3$ & $0.38^{\mathrm{a}}$ \\
& & $272 \pm 29$ & $0.65^{\mathrm{a}}$ \\
Age (years) Mean \pm SD & $70 \pm 6.8$ & $16.8 \pm 3.8$ & $0.45^{\mathrm{a}}$ \\
BMI (kg/m $\left.{ }^{2}\right)$ Mean \pm SD & $26 \pm 35$ & $14(70 \%)$ & $0.14^{\mathrm{a}}$ \\
PSA (ng/ml) Mean \pm SD & $17.4 \pm 4.3$ & $10(47.6 \%)$ & \\
Family history of any & $10(25 \%)$ & $0.92^{\mathrm{a}}$ \\
type of cancer & $5(23.8 \%)$ & $5(60 \%)$ & $0.65^{\mathrm{a}}$ \\
Family history of PCa & $5(66.7 \%)$ & $12(60)$ & $0.001^{\mathrm{a}}$ \\
Smoking & $14(\%)$ & $1(5 \%)$ & \\
ISUP Grade n (\%) & $9(43 \%)$ & $5(25 \%)$ & \\
1 & $4(19 \%)$ & $1(5 \%)$ & \\
2 & $6(28 \%)$ & $8(40 \%)$ & \\
3 & $2(10 \%)$ & $5(25 \%)$ & \\
4 & $0(0 \%)$ & 16.8 & $0.45^{\mathrm{b}}$ \\
5 & 17.4 & 7.5 & $0.49^{\mathrm{b}}$ \\
RASSF1 (\%) & 7.02 & 10 & $0.10^{\mathrm{b}}$ \\
MGMT (\%) & 12.2 & 3.8 & $0.03^{\mathrm{b}}$ \\
PTEN (\%) & 2.5 & & \\
SOCS3 (\%) & & & \\
\hline
\end{tabular}

astudent $t$ test

bPearson correlation

\section{Promoter Methylation of RASSF1A, MGMT, PTEN and SOCS3}

Pyrosequencing was performed to map methylated CPG dinucleotides around bp 173, 253, 153 and 172 in RASSF1A, MGMT, PTEN and SOCS3 gene promoters, respectively (Table 3 ). Little to no difference in methylation levels was detected between the patient and control groups for RASSF1A, MGMT, PTEN, and SOCS3 promoters (Table 1). For promoter methylation levels of RASSF1A, MGMT, and PTEN, the sequencing results confirmed that there was no significant difference between the two patient groups and between the PCa and control groups. However, for the SOCS3 promoter, the methylation levels were significantly higher in patients having locally advanced PCa relative to those with localized PCa $(p<0.05)$ (Table 2).

\section{DISCUSSION}

PCa is an important public health concern, particularly as the global population ages ${ }^{14}$. During 
Table 3. Pyrosequencing primers (Amplification and Sequencing, 5' biotinylation).

\begin{tabular}{|c|c|c|c|c|c|}
\hline Primer Designation & Primer Sequence (5’ $\left.\otimes 3^{\prime}\right)$ & $\begin{array}{l}\text { Orientation } \\
\text { (Forw/Rev) }\end{array}$ & $\begin{array}{l}\text { Annealing } \\
\text { Temp }\left({ }^{\circ} \mathbf{C}\right)\end{array}$ & Thermo-cycles & Product Size (bp) \\
\hline RASSF1A & $\begin{array}{l}\text { AGTTTGGATTTTGGGGGAGG } \\
\text { CAACTCAATAAACTCAAACTCCCC } \\
\text { GTTTTGTGGTTT }\end{array}$ & $\begin{array}{l}\mathrm{F} \\
\mathrm{R} \\
\mathrm{Seq}^{*}\end{array}$ & 62 & 45 & 173 \\
\hline MGMT & $\begin{array}{l}\text { GGTGATTGTAGTTTTTGG A } \\
\text { TCCTATCACAAAAATAATCC } \\
\text { GGTATTAGGAGGGGAGAGATT }\end{array}$ & $\begin{array}{l}\mathrm{F} \\
\mathrm{R} \\
\mathrm{Seq}^{*}\end{array}$ & 58 & 45 & 253 \\
\hline PTEN & $\begin{array}{l}\text { GGTTTTTTTTGTAGGATGGAAATGGT } \\
\text { CCCAAAAAACACCTATCTAAATAAACT } \\
\text { AAATGGTTTTGATTT }\end{array}$ & $\begin{array}{l}\mathrm{F} \\
\mathrm{R} \\
\mathrm{Seq}^{*}\end{array}$ & 61 & 45 & 153 \\
\hline SOCS3 & $\begin{array}{l}\text { TTGGAATTTGTTGTAGGTGAT } \\
\text { ACCTTCTTATAATATTTAATCACTACTC } \\
\text { GGGGGTTTTTGATTAG }\end{array}$ & $\begin{array}{l}\mathrm{F} \\
\mathrm{R} \\
\mathrm{Seq}^{*}\end{array}$ & 60 & 45 & 172 \\
\hline
\end{tabular}

Seq*: Sequencing primer

early-stage PCa, patients exhibit few or no specific symptoms, and early detection of PCa is related to better outcomes ${ }^{8}$. PSA screening is currently the primary method used for early diagnosis of PCa. However, PSA testing does not discriminate between benign and malignant prostate disease, or between indolent and clinically significant PCa. Therefore, robust and reliable markers are needed to screen, diagnose, and monitor PCa neoplasms ${ }^{14,15}$. DNA methylation represents a common, consistent event that may occur early in carcinogenesis and thus it is an attractive biomarker for PCa detection ${ }^{16}$. In this study, we determined the promoter methylation of four tumor suppressor genes, RASSF1A, MGMT, PTEN, and SOCS3, to identify DNA methylation markers that would be suitable for noninvasive diagnostic testing of blood samples from patients having localized and locally advanced PCa. DNA methylation levels were assessed using pyrosequencing, a high-throughput, quantitative method that can detect differences in DNA methylation with high sensitivity.

Examination of pyrosequencing results for RASSF1 A showed that the average methylation level for all PCa patients in this study was higher than that of the control group (17.1\% vs. $15.6 \%)$, but this difference was not statistically significant. No significant difference was also seen in RASSF1 A promoter methylation levels between clinically localized and locally advanced PCa patients (17.4\% vs. $16.8 \%)$. RASSF1 A is a putative tumor suppressor gene located at 3 p21.3 that is functionally associated with cell cycle control, microtubule stabilization, cellular adhesion, motility, and apoptosis. Epigenetic silencing of RASSF1A by hypermethylation of $\mathrm{CPG}$ islands within the promoter region has been observed in various cancer types, including PCa. Although multiple studies have investigated RASSF1A promoter methylation and its association with PCa, no consistent conclusion has been obtained, perhaps due to the diversity of sample materials and testing methods as well as small sample sizes ${ }^{17}$.

For the DNA repair gene MGMT, methylation was detected in $7.1 \%$ and $7.3 \%$ of patients in the PCa group and control group, respectively. We observed little to no difference in MGMT methylation levels between samples obtained from localized and locally advanced cases with PCa (7.02\% vs. $7.2 \%$, respectively, $\mathrm{p}>0.05)$. Our findings were consistent with those of Brait et al. ${ }^{8}$, who also didn't observe any statistically significant association in DNA methylation of MGMT in either 
serum or tumor tissues harvested from PCa patients. Other studies also reported no significant differences in MGMT promoter methylation in PCa cases compared to healthy controls ${ }^{18-20}$. However, as reported in a study by Kang et al. ${ }^{21}, 75.7 \%$ of tissue samples obtained from PCa patients did exhibit MGMT methylation. The reason why the results of this study differ from the others could be because of heterogeneity of prostate tumors.

PTEN is mutated or deleted in PCa as well as in several other tumors. As a tumor suppressor gene, PTEN is involved in PI3-kinase pathway regulation. PTEN family enzymes are involved in cell growth, proliferation, differentiation, and apoptosis $^{22}$. As with RASSF1 A and MGMT, we did not detect any significant change in PTEN methylation levels between the control and PCa patient groups or between the two PCa patient groups ( $p>0.05)$. Whang et al. ${ }^{23}$ suggested that PTEN is inactivated by promoter methylation in advanced PCa. Furthermore, Geybels et al. ${ }^{24}$ reported that deletion or mutation of PTEN may enhance tumor progression by inducing DNA methylation in patients with PCa recurrence. Notably, our patient population did not contain any cases of PCa recurrence, which could explain the reason why any changes in PTEN promoter methylation were not observed.

We did detect a statistically significant increase in SOCS3 promoter methylation levels in patients who had locally advanced PCa compared to those who had localized PCa $(2.2 \%$ and $2.3 \%$, respectively; $p<0.05)$. Meanwhile, there was no significant difference in SOCS3 promoter methylation levels between the control and the PCa patient group. SOCS3 is a negative regulator of the IL6/ JAK/STAT3 pathway that is linked to development of PCa and castration resistance. Upon activation of the IL6/JAK/STAT3 signaling cascade, STAT3 was shown to enhance the activation of androgen receptor and contribute to progression to castration resistance in PCa. Increased STAT3 levels are observed both in primary and metastatic PCa.
As a STAT3 inhibitor, SOCS3 expression is commonly inactivated by promoter hypermethylation in a wide range of tumor types, including PCa. Handle et al. ${ }^{25}$ and Pierconti et al. ${ }^{26}$ proposed that SOCS3 promoter methylation may be a potential biomarker to identify an aggressive subset of PCa tumors. They also reported that SOCS3 methylation is correlated with medium and high grade Gleason scores, and poor clinical results. Similarly, our data suggested that hypermethylation of the SOCS3 promoter was more frequent in blood samples obtained from patients with locally advanced PCa and was significantly associated with high ISUP grade (Grades 4 and 5; Table 2). One limitation of our study is the small number subjects, both with PCa and healthy controls. As such, our findings require validation in a larger sample.

\section{CONCLUSION}

Our findings suggest that SOCS3 promoter methylation has a potential for use as a noninvasive epigenetic biomarker for the diagnosis of locally advanced PCa. At the diagnostic stage of PCa, epigenetic markers as well as clinicopathological features are valuable and could be determinants for selection of effective treatments. Further studies will be needed to assess the possible clinical benefit of SOCS3 promoter methylation as an epigenetic diagnostic biomarker of PCa.

\section{REFERENCES}

1. Dasgupta P, Baade PD, Aitken JF, Ralph N, Chambers SK, Dunn J. Geographical Variations in Prostate Cancer Outcomes: A Systematic Review of International Evidence. Front Oncol. 2019;9:238. [CrossRef]

2. Wu Y, Davison J, QuX, et al. Methylation profiling identified novel differentially methylated markers including OPCML and FLRT2 in prostate cancer. Epigenetics.2016;11:24758. [CrossRef]

3. Martin NE. New developments in prostate cancer biomarkers. Curr Opin Oncol. 2016;3:248-52. [CrossRef]

4. Eifler JB, Feng Z, Lin BM, et al. An updated prostate cancer staging nomogram (Partin tables) based on cases from 2006 to 2011. BJU Int. 2013;111:22-9. [CrossRef]

5. Moschini M, Spahn M, Mattei A, Cheville J, Karnes RJ. Incorporation of tissue-based genomic biomarkers into localized prostate cancer clinics. BMC Med. 2016;14:67. [CrossRef] 
6. Grogan J, Gupta R, Mahon KL, et al. Predictive value of the 2014 International Society of Urological Pathology grading system for prostate cancer in patients undergoing radical prostatectomy with long-term follow-up. BJU Int. 2017;120:651-8. [CrossRef]

7. Yegnasubramanian S, De Marzo AM, Nelson WG. Prostate Cancer Epigenetics: From Basic Mechanisms to Clinical Implications. Cold Spring Harb Perspect Med. 2019;9:pii:a030445. [CrossRef]

8. Brait M, Banerjee $M$, Maldonado L, et al. Promoter methylation of MCAM, ER $\alpha$ and $E R \beta$ in serum of early stage prostate cancer patients. Oncotarget. 2017;8:15431-40. [CrossRef]

9. Luo JH, Ding Y, Chen R, et al. Genome-wide methylation analysis of prostate tissues reveals global methylation patterns of prostate cancer. Am J Pathol. 2013;182:202836. [CrossRef]

10. Blute ML Jr, Damaschke NA, Jarrard DF. The epigenetics of prostate cancer diagnosis and prognosis: update on clinical applications. Curr Opin Urol. 2015;25:83-8. [CrossRef]

11. Mahon KL, Qu W, Lin HM, et al. Serum Free Methylated Glutathione S-transferase 1 DNA Levels, Survival, and Response to Docetaxel in Metastatic, Castration-resistant Prostate Cancer: Post Hoc Analyses of Data from a Phase 3 Trial. Eur Urol. 2018;19:pii: S0302-2838(18)30855-8. [CrossRef]

12. Martignano F, Gurioli G, Salvi S, et al. GSTP1 Methylation and Protein Expression in Prostate Cancer: Diagnostic Implications. Dis Markers. 2016;2016:4358292. [CrossRef]

13. Kim YJ, Yoon HY, Kim SK, et al. EFEMP1 as a novel DNA methylation marker for prostate cancer: array-based DNA methylation and expression profiling. Clin Cancer Res. 2011;17:4523-30. [CrossRef]

14. Moreira-Barbosa C, Barros-Silva D, Costa-Pinheiro P, et al. Comparing diagnostic and prognostic performance of two-gene promoter methylation panels in tissue biopsies and urines of prostate cancer patients. Clin Epigenetics. 2018;10:132. [CrossRef]

15. Brikun I, Nusskern D, Decatus A, Harvey E, Li L, Freije D. A panel of DNA methylation markers for the detection of prostate cancer from FV and DRE urine DNA. Clin Epige- netics. 2018;10:91. [CrossRef]

16. Zhao S, Leonardson A, Geybels MS, et al. A five-CpG DNA methylation score to predict metastatic-lethal outcomes in men treated with radical prostatectomy for localized prostate cancer. Prostate. 2018;28. [CrossRef]

17. Ge YZ, Xu LW, Jia RP, et al. The association between RASSF1 A promoter methylation and prostate cancer: evidence from 19 published studies. Tumour Biol. 2014;35:388190. [CrossRef]

18. Jerónimo C, Henrique R, Hoque MO, et al. A quantitative promoter methylation profile of prostate cancer. Clin Cancer Res.2004;10:8472-8. [CrossRef]

19. Yegnasubramanian S, Kowalski J, Gonzalgo ML, et al. Hypermethylation of CPG Islands in Primary and Metastatic Human Prostate Cancer. Cancer Res. 2004;64:1975-86. [CrossRef]

20. Tang D, Kryvenko ON, Mitrache N, et al. Methylation of the RARB Gene Increases Prostate Cancer Risk in Black Americans. J Urol. 2013;190:317-24. [CrossRef]

21. Kang GH, Lee S, Lee HJ, Hwang KS. Aberrant CpG island hypermethylation of multiple genes in prostate cancer and prostatic intraepithelial neoplasia. J Pathol. 2004;202:233-40. [CrossRef]

22. Filella X, Fernández-Galan E, Fernández Bonifacio R, Foj L. Emerging biomarkers in the diagnosis of prostate cancer. Pharmgenomics Pers Med. 2018;11:83-94. [CrossRef]

23. Whang YE, Wu X, Suzuki $\mathrm{H}$, et al. Inactivation of the tumor suppressor PTEN/MMAC1 in advanced human prostate cancer through loss of expression. Proc Natl Acad Sci USA. 1998;.95:5246-50. [CrossRef]

24. Geybels MS, Fang M, Wright JL, et al, PTEN loss is associated with prostate cancer recurrence and alterations in tumor DNA methylation profiles. Oncotarget. 2017;8:84338-48. [CrossRef]

25. Handle F, Erb HH, Luef B, et al. SOCS3 Modulates the Response to Enzalutamide and Is Regulated by Androgen Receptor Signaling and CpG Methylation in Prostate Cancer Cells. Mol Cancer Res. 2016;14:574-85. [CrossRef]

26. Pierconti F, Martini M, Pinto F, et al. Epigenetic silencing of SOCS3 identifies a subset of prostate cancer with an aggressive behavior. Prostate. 2011;71:318-25. [CrossRef] 